\title{
RISET SITOTOKSIK CAMPURAN EKSTRAK DAUN SIRSAK (Annona muricata L) DAN KULIT BUAH MANGGIS (Garcinia mangostana L) PADA SEL VERO DAN AML12
}

\author{
Tuty Erlina Mardja, Fitria Rahmi, Eka Rusmawati, Rina Adriany, Murtiningsih, \\ Herlina B. Setijanti, Tepy Usia \\ Pusat Riset Obat dan Makanan, Badan POM RI \\ Jl. Percetakan Negara No.23 Jakarta \\ Email: tuty_erlina@yahoo.com
}

\begin{abstract}
ABSTRAK
Campuran Daun sirsak dan Kulit buah manggis sekarang ini banyak digunakan sebagai fitoterapi penyakit kanker dan antioksidan. Tetapi penggunaan bahan ini belum diketahui data keamanannya. Tujuan dilakukan penelitian adalah untuk mengetahui efek sitotoksik campuran ekstrak daun sirsak dan kulit buah manggis terhadap sel vero dan sel AML12. Uji sitotoksik dapat memprediksi keberadaan senyawa yang bersifat toksik secara in vitro menggunakan sel normal atau sel yang telah mengalami transformasi. Uji ini menggunakan 2 jenis cell line, yaitu sel vero dan sel AML12. Sampel berupa simplisia daun sirsak dan kulit buah manggis yang dibuat ekstrak dengan menggunakan etanol 96\%. Konsentrasi uji yang digunakan adalah $100 ; 50 ; 25 ; 12,5 ; 6,25$ dan $3,125 \mu \mathrm{g} / \mathrm{mL}$ untuk sel vero dan 500; $250 ; 125 ; 62,5 ; 31,25$ dan $15,625 \mu \mathrm{g} / \mathrm{mL}$ untuk sel AML12. Kultur sel dilakukan di wellplate 96 diinkubasi didalam inkubator $\mathrm{CO}_{2}$ pada suhu $37^{\circ} \mathrm{C}$ selama 24 jam kemudian ditambahkan sampel uji dan selanjutnya diinkubasi kembali didalam inkubator $\mathrm{CO}_{2}$ pada suhu $37^{\circ} \mathrm{C}$ selama 24 jam. Langkah selanjutnya uji MTT dan kemudian dibaca dengan ELISA reader pada panjang gelombang 570nm. Diperoleh hasil sebagai berikut: $\mathrm{IC}_{50} 55,97 \mu \mathrm{g} / \mathrm{mL}$ pada sel vero, dan 43,292 $\mu \mathrm{g} / \mathrm{mL}$ pada sel AML12. Kesimpulannya sampel campuran ekstrak daun sirsak dan kulit buah manggis ini mempunyai efek toksik terhadap sel vero dan sel AML12 $\left(\mathrm{IC}_{50}<100 \mu \mathrm{g} / \mathrm{mL}\right)$.
\end{abstract}

Kata kunci: Sitotoksik, Daun sirsak, Kulit buah manggis, sel vero, sel AML12, IC 50

\begin{abstract}
Mix of soursop leaves and mangosteen pericarp use as cancer phytotherapy and antioxidant, but it is not yet known its toxicities data. The aim of this study was evaluate cytotoxicity effect of mix of soursop leaves and mangosteen pericarps extract on vero cells and AML12 cells. Toxicity study is one ways to predict the presence of toxic compounds using normal cells or cells that have undergone a transformation. That study was using vero cell and AML12. Samples was ethanolic extract of soursop leaves and mangosteen pericarp. The test dose were $100 ; 50 ; 25 ; 12,5 ; 6,25$ dan $3,125 \mu \mathrm{g} / \mathrm{mL}$ in vero cell and $500 ; 250 ; 125 ; 62,5$; 31,25 dan $15,625 \mu \mathrm{g} / \mathrm{mL}$ in AML12. Cells were cultured in well plate 96 and incubated in $\mathrm{CO}_{2}$, temperature $37^{\circ} \mathrm{C}$ for 24 hours and then added samples and incubated incubated in $\mathrm{CO}_{2}$, temperature $37^{\circ} \mathrm{C}$ for 24 hours. Cell was added MTT and read with ELISA reader. The results showed $\mathrm{IC}_{50} 55,97 \mu \mathrm{g} / \mathrm{mL}$ in vero cells and 43,292 $\mu \mathrm{g} / \mathrm{mL}$ in AML12. Conclusion of
\end{abstract}


this study is ethanolic extract of soursop leaves and mangosteen pericarps has toxicity effect in vero cells and AML12 cells ( $\mathrm{IC}_{50}<100 \mu \mathrm{g} / \mathrm{mL}$ ).

Keywords: cytotoxiciy, soursop leaves, mangosteen pericarp, vero cells, AML12 cells, IC 50

\section{LATAR BELAKANG}

Akhir-akhir ini banyak beredar produk obat tradisional seperti daun sirsak, kulit buah manggis dan campurannya. Produk ini diklaim dapat mendukung dalam pengobatan kanker dan dapat sebagai antioksidan. Adanya anggapan masyarakat bahwa obat tradisional aman sehingga obat ini digunakan dengan tanpa memperhatikan dosis penggunaan. Hal ini karena kurangnya informasi akan keamanan obat tradisional, sehingga Pusat Riset Obat dan Makanan, Badan POM RI melakukan evaluasi keamanan obat tradisional yang sering digunakan oleh masyarakat.

Daun sirsak (Anonna muricata) telah digunakan sebagai fito-terapi berbagai penyakit seperti kanker, anti mikroba berspektrum luas untuk mengatasi infeksi bakteri dan jamur serta sebagai anti helmintik (Olakunle et al., 2014; Solomon-Wisdom et al, 2014). Pada daunnya juga ditemukan mengandung anti oksidan, menghambat anti inflamasi dan efek anti analgesik, menginduksi sitotoksisitas dan apoptosis pada T47D kanker payudara, aktivitas anti virus dan anti diabetes. Secara fitokimia daun A. muricata mengandung alkaloid, minyak atsiri dan acetogenin. Acetogenin ini menunjukkan toksik selektif terhadap beberapa sel kanker tanpa merusak sel sehat (Pieme et al., 2014).

Kulit buah manggis (Garcinia mangostana $\mathrm{L}$ ) sering digunakan sebagai obat tradisional untuk mengatasi nyeri perut, diare, disentri, luka-luka, infeksi dan juga sebagai anti oksidan, anti bakteri, anti tumor. Kulit manggis ini dilaporkan sebagai sumber mangostin, tannin, xanthone, chrysanthemin, garcinone, gartanin. Xanthone merupakan subtansi kimia alami yang tergolong senyawa polyphenolic (Moongkarndi et al., 2004).

Uji sitotoksik merupakan salah satu pengembangan metode untuk memprediksi keberadaan senyawa yang bersifat toksik dengan menggunakan sel normal atau telah mengalami transformasi (Obidike and Oluwakanyinsola, 2013). Sel hidup (viabel) dengan metabolisme aktif akan mengubah MTT menjadi produk formazan yang berwarna ungu dengan absorbansi maksimal 570nm. Ketika sel mengalami kematian, maka sel tersebut kehilangan kemampuan mengubah MTT menjadi formazan, sehingga pembentukan warna ini berguna sebagai penanda untuk sel hidup (viabel) (Riss, et al., 2013).

Balantyne (1999) membuat kategori sitotoksik untuk bahan alam berdasarkan jumlah $\mathrm{IC}_{50}$, seperti tercantum dalam Tabel 1.

Tabel 1. Klasifikasi sitotoksik untuk bahan alam (Balantyne, 1999).

\begin{tabular}{cc}
\hline $\mathrm{IC}_{50}$ & Kategori \\
\hline $10 \mu \mathrm{g} / \mathrm{mL}\left(10^{6} \mathrm{Sel} / \mathrm{mL}\right)<\mathrm{IC}_{50}$ & Sangat toksik \\
$10 \mu \mathrm{g} / \mathrm{mL}<\mathrm{IC}_{50}<100 \mu \mathrm{g} / \mathrm{mL}$ & Toksik \\
$100 \mu \mathrm{g} / \mathrm{mL}<\mathrm{IC}_{50}<1000 \mu \mathrm{g} / \mathrm{mL}$ & Moderat \\
$\mathrm{IC}_{50}>1000 \mu \mathrm{g} / \mathrm{mL}$ & Tidak toksik \\
\hline
\end{tabular}

\section{METODOLOGI}

\section{Sampel Uji}

Simplisia daun sirsak dan kulit buah manggis diperoleh dari Biofarmaka,Bogor. 


\section{Sel uji}

Sel Vero dan sel AML12 yang diperoleh dari ATCC.

\section{Bahan}

Etanol, Trypsin-

Ethylenediaminetetraacetic acid (EDTA) 0,25\%, medium M199, medium Ham's F12, Dulbecco's Minimum Esential Media (DMEM), medium ITS (Insulin, Transferrin, Selenium), Fetal Bovine Serum (FBS), Dimethyl Sulfoxide (DMSO), Natrium Bikarbonat (NaHCO3), penicillin/streptomycin, 3(4,5-Dimethylthiazol-2-yl)-2,5-

Diphenyltetrazolium Bromide (MTT), Phosphat Buffer Saline (PBS), larutan isopropanol-HCl.

\section{Peralatan}

Inkubator $\mathrm{CO}_{2}$-Thermoscience, Mikroskop inverted-Nikon TS 100, haemocytometer, Elisa Reader-Dynex, Magellan Biosciences, SentrifugeHettich, Laminar Air Flow (LAF)-BSL-II Holten LaminAir-Thermo Electron Corporation, tabung gelas $5 \mathrm{ml}$, mikropipet-Eppendorf, pengocok magnetik, autoclave-Tomy, oven sterilisasi, lemari pendingin-Toshiba, freezer-Denpoo, deep freezer-Sneijder, timbangan-Mettler Toledo, dan shaker.

\section{Prosedur}

\section{Pembuatan Ekstrak Etanol serbuk simplisia}

Di timbang 100 gram masingmasing serbuk simplisia daun sirsak (Annona muricata), dan kulit buah manggis (Garcinia mangostana) kemudian dimaserasi dengan 1 L Etanol 96\%, selama 18 jam. Maserat dipisahkan dengan cara filtrasi. Filtrat diuapkan dengan penguap vakum tekanan rendah hingga diperoleh ekstrak kental. Rendemen yang diperoleh dihitung dengan cara membandingkan persentase bobot (b/b) ekstrak kental dengan bobot serbuk simplisia. Rendemen harus mencapai angka sekurang-kurangnya seperti yang ditetapkan dalam monografi ekstrak.

\section{Pembuatan larutan uji \\ Ditimbang sejumlah ekstrak} sampel, dan dicampur dengan perbandingan 1:1 kemudian ditambahkan larutan DMSO hingga diperoleh konsentrasi larutan $125 \mathrm{mg} / \mathrm{mL}$, dimana larutan ini digunakan sebagai larutan induk. Dari larutan induk tersebut dibuat seri konsentrasi $100 ; 50 ; 25 ; 12,5 ; 6,25$; dan $3,125 \mu \mathrm{g} / \mathrm{mL}$ untuk Sel vero dan 500; $250 ; 125 ; 62,5 ; 31,25$ dan $15,625 \mu \mathrm{g} / \mathrm{mL}$ untuk sel AML12 dengan menggunakan pelarut media kultur yang sesuai untuk masing-masing sel. Penyiapan sediaan uji dilakukan secara aseptis.

\section{Uji Sitotoksisitas menggunakan MTT Assay}

Sejumlah $100 \mu \mathrm{L}$ suspensi sel dengan kepadatan $2 \times 10^{4}$ dimasukkan ke dalam plate 96 well dan diinkubasi dalam inkubator $\mathrm{CO}_{2} 5 \%$ dengan suhu $37^{\circ} \mathrm{C}$ selama 24 jam. Kemudian ditambahkan $100 \mu \mathrm{L}$ larutan uji hasil ekstraksi dengan seri konsentrasi yang telah dibuat, selanjutnya diinkubasi dalam inkubator $\mathrm{CO}_{2} 5 \%$ pada suhu $37^{\circ} \mathrm{C}$ selama 24 jam. Pada akhir inkubasi, medium pada masing-masing sumuran dibuang dan sumuran dicuci dengan $100 \mu \mathrm{L}$ PBS, selanjutnya pada masing-masing sumuran ditambahkan $100 \mu \mathrm{L}$ medium baru yang mengandung $0,5 \mathrm{mg} / \mathrm{mL}$ MTT. Plate diinkubasi lagi pada suhu $37{ }^{\circ} \mathrm{C}$ selama 4 jam.

Kemudian sumuran dicuci dengan PBS $100 \mu \mathrm{L}$. Selanjutnya kedalam tiap sumuran ditambahkan $100 \mu \mathrm{L}$ larutan $\mathrm{HCl}$-isopropanol dan dikocok dengan shaker selama 10 menit. Serapan dibaca dengan ELISA reader pada panjang gelombang $570 \mathrm{~nm}$. 
Riset Sitotoksik Campuran Ekstrak Daun Sirsak (Annona muricata L) dan Kulit Buah Manggis (Garcinia mangostana L) pada Sel Vero dan AML12

Persen viabilitas sel dihitung dengan rumus:

$$
\% \text { viabilitas sel }=\frac{\text { Abs. Perlakuan-Abs. blanko }}{\text { Abs. } \text { kontrol sel-Abs. blanko }} \times 100 \%
$$

Setelah didapatkan nilai \% viabilitas sel kemudian dilakukan penghitungan nilai $\mathrm{IC}_{50}$, caranya dengan membuat plot grafik hubungan antara log konsentrasi vs persentase viabilitas sel menggunakan program Microsoft Office Excel untuk mendapatkan persamaan regresi linier. Nilai $\mathrm{IC}_{50}$ adalah konsentrasi yang menyebabkan terjadinya viabilitas sel sebesar $50 \%$.

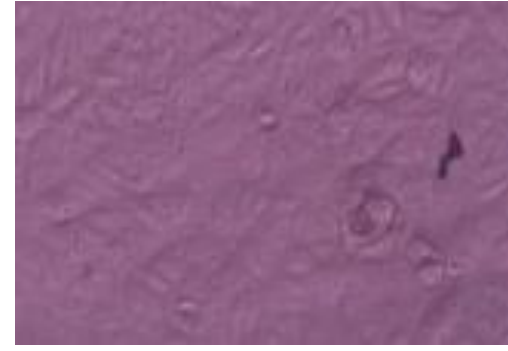

(a)

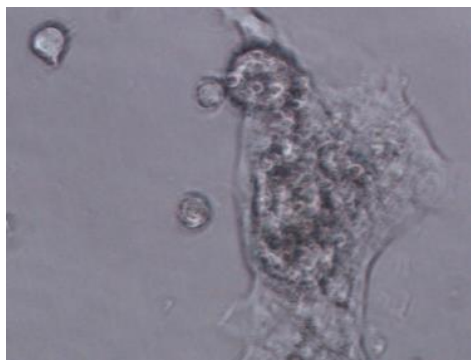

(c)

\section{HASIL DAN PEMBAHASAN}

Pada sampel campuran ekstrak sirsak dan ekstrak kulit buah manggis dipaparkan dalam well plate 96 yang sebelumnya dikultur dengan sel vero dan sel AML12 menunjukkan gambar sebagai berikut:

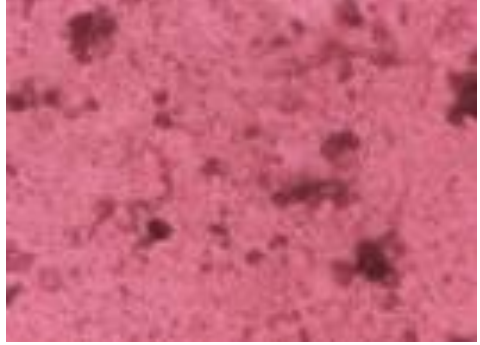

(b)

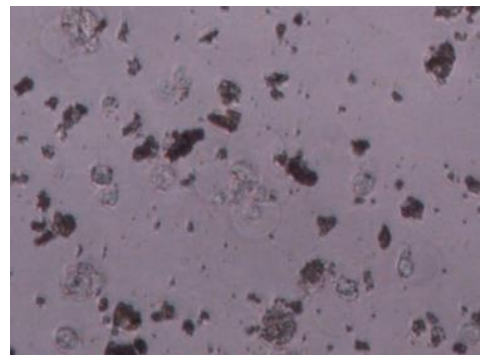

(d)

Gambar 1 (a) Kontrol sel Vero (a) Kontrol sel AML 12 (c) Sel vero yang diberikan sampel campuran ekstrak daun sirsak dan ekstrak manggis dengan dosis tinggi (d) Sel AML 12 yang diberikan sampel campuran ekstrak daun sirsak dan ekstrak manggis dengan dosis tinggi

Pada sel vero dan sel AML12 yang dipaparkan sampel campuran ekstrak daun sirsak dan kulit buah manggis ini menunjukkan banyak sel mati yang semakin tambah banyak seiring bertambahnya dosis, sehingga produk yang mengandung campuran ekstrak tersebut bersifat sitotoksik. 


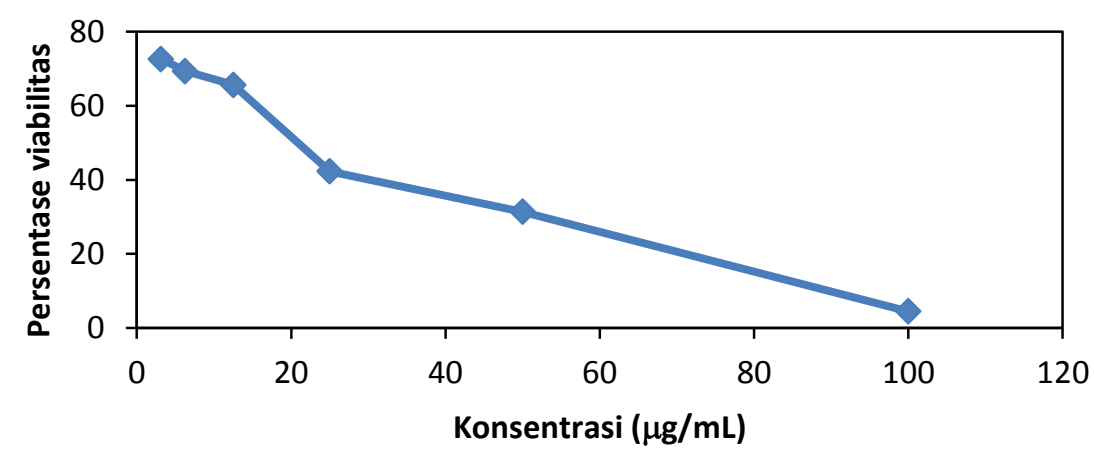

(a)

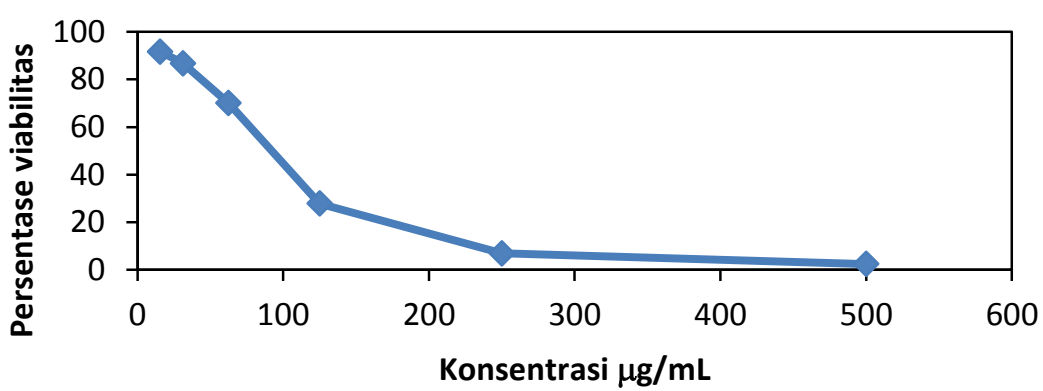

(b)

Gambar 2 (a) Persentase sel viabel dari sel vero terhadap konsentrasi sampel campuran ekstrak daun sirsak dan kulit buah manggis (b) Persentase sel viabel dari sel AML 12 terhadap konsentrasi sampel campuran ekstrak daun sirsak dan kulit buah manggis

Pada uji sitotoksik dengan sel Vero maka diperoleh hasil bahwa persamaan regresinya $\mathrm{y}=-0,7026 \mathrm{x}+$ 70,687 dengan $\mathrm{R}^{2}=0,9465$ sehingga dapat dihitung bahwa $\mathrm{IC}_{50}=55,97 \mu \mathrm{g} / \mathrm{mL}$. Menurut Balantyne (1999) IC IC $_{50}$ yang berkisar $10 \mu \mathrm{g} / \mathrm{mL}$ sampai dengan 100 $\mu \mathrm{g} / \mathrm{mL}$ tergolong toksik, sehingga ekstrak daun sirsak dan kulit buah manggis ini tergolong toksik terhadap sel vero. Hal ini selaras dengan penelitian yang dilakukan oleh Quispe et al. (2007) ekstrak etanolik daun sirsak dapat dapat menghambat pertumbuhan sel vero dan mempunyai $\mathrm{IC}_{50} \quad 43 \mu \mathrm{g} / \mathrm{mL}$. Beberapa peneliti menduga bahwa senyawa acetogenin (Squamocin A, B, C dan D) dan annotemoyin 1 and 2 dari daun sirsak yang mempunyai aktivitas sitotoksik (Padma et al, 2009; Yang et al., 2009). Acetogenin ini menghambat NADH-ubiquinon oksidoreduktase (komplek I) pada mitokondria dan menghambat produksi ATP sehingga menyebabkan apoptosis (Morre et al, 1995; Kojima \& Tanaka, 2009). Efek sitotoksik pada penelitian ini dengan menggunakan sel vero (sel ginjal normal) terutama dengan konsentrasi tinggi bertentangan dengan penelitian Anne-Isabelle et al., (1997) yang menyebutkan acetogenin ini sangat selektif, hanya menyerang sel kanker yang mempunyai banyak ATP dan senyawa ini tidak menyerang sel normal.

Pada uji dengan sel AML12 diperoleh persamaan regresi dapat diperoleh $\mathrm{y}=-0,186 \mathrm{x}+78,13$ dengan $\mathrm{R}^{2}$ $=0,7355$ sehingga dapat dihitung bahwa $\mathrm{IC}_{50}=43,292 \mu \mathrm{g} / \mathrm{mL}$. Menurut Balantyne (1999) $\mathrm{IC}_{50}$ yang berkisar $10 \mu \mathrm{g} / \mathrm{mL}$ sampai dengan $100 \mu \mathrm{g} / \mathrm{mL}$ tergolong toksik, sehingga ekstrak daun sirsak dan 
kulit buah manggis ini tergolong toksik terhadap sel AML12. Hal ini selaras dengan penelitian yang dilakukan oleh Rivanti et al. (2012) bahwa ekstrak etanol kulit manggis mempunyai $\mathrm{IC}_{50}$ pada sel T47D $2.07 \mu \mathrm{g} / \mathrm{ml}$ dan pada sel Hela IC $_{50}$ $10.58 \mu \mathrm{g} / \mathrm{mL}$. Kulit manggis ini mengandung senyawa aktif yang terutama $\alpha$-mangostin dan $\beta$-mangostin yang bila dilakukan uji sitotoksik yang dibandingkan dengan cisplatin, maka ekstrak ini mempunyai efek toksik hampir 2 kali lipat (Aisha et al, 2012).

Menurut Sato et al. (2004) induksi $\mathrm{Ca}^{2+}$-ATPase-dependent apoptosis dari sel melalui jalur mitochondria disebabkan oleh $\alpha$ mangostin, sedangkan penghambatan $\mathrm{Ca}^{2+}$-ATPase dapat menyebabkan induksi pelepasan sitokrom-C sehingga menimbulkan apoptosis.

\section{KESIMPULAN}

Sampel campuran ekstrak daun sirsak dan kulit buah manggis mempunyai $\mathrm{IC}_{50}: 55,97 \mu \mathrm{g} / \mathrm{mL}$ pada sel vero, dan $43,292 \mu \mathrm{g} / \mathrm{mL}$ pada sel AML12, sehingga berdasarkan tabel klasifikasi sitotoksik untuk bahan alam, campuran ekstrak tersebut termasuk kategori toksik terhadap sel vero dan sel AML 12.

\section{DAFTAR PUSTAKA}

1. Olakunle, Sanni, Obidoa Onyechi, Omale James, 2014, Toxicity, antilipid peroxidation, invitro and invivo evaluation of antioxidant activity of Annona muricata ethanol stem bark extract, American Journal of Life Sciences 2014; 2(5): 271-277

2. Solomon-Wisdom, G.O, Ugoh, S.C and Mohammed, .B., 2014, Phytochemical Screening and Antimicrobial activities of Annona muricata (L) leaf extract, American Journal of Biological, Chemical and Pharmaceutical Sciences Vol. 2, No. 1, January 2014, PP: 01-07, ISSN:
2328 - 6814 (Online), Available online at http://www.ajbcps.com/

3. Pieme, Constant Anatole, Santosh Guru Kumar, Mireille Sylviane Dongmo, Bruno Moukette Moukette, Fabrice Fekam Boyoum, Jeanne Yonkeu Ngogang and Ajit Kumar Saxena, Antiproliferative activity and induction of apoptosis by Annona muricata (Annonaceae) extract on human cancer cells, BMC Complementary and Alternative Medicine 2014, 14:516, http://www.biomedcentral.com/14726882/14/516

4. Moongkarndi, Primchanien, Nuttavut Kosema, Sineenart Kaslungka, Omboon Luanratana, Narongchai Pongpan, Neelobol Neungton, 2004, Antiproliferation, antioxidation and induction of apoptosis by Garcinia mangostana (mangosteen) on SKBR3 human breast cancer cell line, Journal of Ethnopharmacology 90 (2004) 161-166,

http://livingbyheart.tripod.com/sitebui ldercontent/sitebuilderfiles/-

garcinia_mangostana_breast_cancer_ study.pdf

5. Obidike Ifeoma and Salawu Oluwakanyinsola, 2013, Screening of Herbal Medicines for Potential Toxicities, New Insights into Toxicity and Drug Testing, intech, http://cdn.intechopen.com/pdfswm/42020.pdf

6. Riss, Terry L, Richard A Moravec, Andrew L Niles, Helene A Benink, Tracy J Worzella, and Lisa Minor, 2013, Cell Viability Assays, Assay Guidance Manual [Internet], Published May 1, 2013, http://www.ncbi.nlm.nih.gov/books/N BK144065/, tanggal 21 April 2015

7. Quispe, Angel, David Zavala, Margarita Posso, José Rojas, Abraham Vaisberg, 2007, Annona muricata (Guanabana) Citotoxic Effect In Lung And Abdominal Neoplasms Cell Lines, CIMEL 2007 Vol. $12 \mathrm{~N}^{\circ} 1$ 
8. Padmaa PM, Chansouria JPN, Khosa RL. Wound Healing Activity of Annona muricata extract. J Pharm Res. 2009;2(3):404-6.

9. Yang, H. J., X. Li, N. Zhang, J. W. Chen and M. Y. Wang, "Two New Cytotoxic Acetogenins from Annona squamosa," Journal of Asian Natural Products Research, Vol. 11, No. 3, 2009, pp. 250-256. doi:10.1080/10286020802682916

10. Morré DJ, de Cabo R, Farley C, Oberlies NH, McLaughlin JL. Mode of action of bullatacin, a potent antitumor acetogenin:Inhibition of $\mathrm{NADH}$ oxidase activity of HeLa and HL-60, but not liver, plasma membranes. Life Sci. 1995;56:343-8.

11. Kojima N, Tanaka T. Medicinal Chemistry of Annonaceous Acetogenins: Design, Synthesis, and Biological Evaluation of Novel Analogues. Molecules. 2009;14:362161.

12. Anne-Isabelle, W., R. Hocquemiller, A. Laurens and A. Cavé, "Glaucafilin, an Acetogenin from Annona glauca,"
Journal of Phytochemistry, Vol. 44, No. 8, 1997, pp. 1537-1540

13. Rivanti, Erlina, Annishfia Lailatur Rohmah, Herwandhani Putri, Prisnu Tirtanirmala, and Dyaningtyas Dewi Putri Pamungkas, 2012, Ethanolic Extract of Mangosteen (Garcinia mangostana) Peel Inhibits T47D and Hela Cells Line Proliferation Via NfқB Pathway Inhibition, Indonesian Journal of Cancer Chemoprevention, 2012, 3 (2): 392-398 ISSN: 2088 0197 (13 Januari 2016)

14. Aisha, Abdalrahim F A, Khalid M Abu-Salah, Zhari Ismail and Amin Malik Shah Abdul Majid, 2012, In vitro and in vivo anti-colon cancer effects of Garcinia mangostana xanthones extract, BMC Complementary and Alternative Medicine

15. Sato A, Fujiwara H, Oku H, Ishiguro K, Ohizumi Y. 2004. Alphamangostin induces $\mathrm{Ca} 2+-\mathrm{ATPase}-d e p e n d e n t$ apoptosis via mitochondrial pathway in PC12 cells. J Pharmacol Sci 95: 3340. 